\title{
ANALISIS PENGARUH KINERJA KEUANGAN TERHADAP TNGKAT KESEHATAN BANK SYARIAH DENGAN MENGGUNAKAN METODE RGEC PERIODE 2012 - 2016
}

\author{
Amilia Paramita Sari \\ Fakultas Ekonomi Universitas Batanghari \\ amiliaps18@gmail.com
}

\begin{abstract}
This study aims to determine how the soundness of the Sharia Bank in the period 2012 - 2016. This type of research is descriptive research with quantitative approach. The variables used were risk profile as measured by the ratio of NPF and FDR, good corporate governance is measured through self-assessment results, profitability as measured by ROA and NIM, and Capital as measured by the ratio of CAR. The data used in this study is secondary data in the form of financial statements of 2012-2016 that have been audited by independent auditors and has been published. This study uses four samples, Bank Muamalat, Bank BRI Syariah, Bank Syariah Mandiri, and Bank BNI Syariah. The results showed that: (1) Variables The magnitude of the effect of NPF, FDR, GCG, ROA, NIM and $C A R$ on bank soundness can be concluded that there are significant influence simultaneously. Independent variable able to explain dependent variable equal to 64\%. (2) The variable that has significant partial effect on bank soundness is GCG variable. While the variable of NPF, FDR, ROA, NIM and CAR give insignificant influence to bank soundness. (3) Predicates of bank performance during the period 2012-2016 using RGEC method known to exist 92\% of banks indicate that the condition of the bank is stable. This means that commercial banks can be categorized as "soundness" bank.
\end{abstract}

Keywords: Accounting, Health Assessment, Sharia Bank. risk profile, GCG

\section{PENDAHULUAN}

Pesatnya perkembangan perbankan di Indonesia mengakibatkan sangat diperlukan suatu pengawasan terhadap kinerja bank tersebut. Bank Indonesia sebagai bank sentral memiliki suatu kontrol terhadap bank-bank untuk mengetahui bagaimana keadaan keuangan serta kegiatan usaha masing-masing bank. Kebijakan perbankan yang dikeluarkan dan dilaksanakan Bank Indonesia pada dasarnya adalah ditujukan untuk menciptakan dan memelihara kesehatan, baik secara individu maupun perbankan secara sistem. (Adisetiawan, 2012a)

Kesehatan atau kondisi keuangan dan non keungan bank merupakan kepentingan semua pihak stakeholder, baik pemilik, manajemen, masyarakat pengguna jasa bank (nasabah) serta Bank Indonesia selaku otoritas pengawasan bank. Kondisi bank tersebut dapat digunakan oleh pihak-pihak tersebut untuk mengevaluasi kinerja bank dalam menerapkan prinsip kehati-hatian, kepatuhan terhadap ketentuan risiko yang berlaku dan manajemen risiko. Perkembangan industri perbankan, terutama produk dan jasa yang semakin kompleks dan beragam akan meningkatkan eksposur risiko yang dihadapi oleh bank. (Adisetiawan, 2012b)

Penilaian kesehatan bank dapat ditinjau dari berbagai aspek yang bertujuan untuk menentukan apakah bank tersebut dalam kondisi yang sehat, cukup sehat, kurang sehat atau tidak sehat. Menurut Bank Of Settlement, bank dapat dikatakan 
sehat apabila bank tersebut dapat melaksakan kontrol terhadap aspek modal, aktiva, rentabilitas, manajemen dan aspek likuiditasnya. Pengertian kesehatan bank menurut Bank Indonesia sesuai dengan Undang Undang RI No. 7 tahun 1992 Tentang perbankan Pasal 29 adalah bank dikatakan sehat apabila bank tersebut memenuhi ketentuan kesehatan bank dengan memperhatikan aspek permodalan, kualitas aset, kualitas manajemen, kualitas rentabilitas, likuiditas, solvabilitas, dan aspek lain yang berhubungan dengan usaha bank. (Adisetiawan, 2012b)

Bank syariah adalah bank yang beroperasi sesuai dengan prinsip-prinsip yang ada dalam ajaran Islam, berfungsi sebagai badan usaha yang menyalurkan dana dari dan kepada masyarakat atau sebagai lembaga perantara keuangan. Islamic banking merupakan unit sistem ekonomi Islam yang beroperasi dengan doktrin dan larangan terhadap praktik riba. Perbankan Islam memiliki peran strategis dalam meningkatkan kesejahteraan umat, melalui proses intermediasi kegiatan penghimpunan dan penyaluran dana maupun penyediaan jasa keuangan lainnya, berlandaskan prinsip-prinsip syariah. Ketika sistem perbankan konvensional tidak stabil karena sistem moneter dan memerlukan biaya yang begitu besar untuk mempertahankannya, perbankan syariah justru mampu menyelamatkan sebagian ekonomi umat. Kemampuan survival perbankan Islam dalam era krisis, telah menarik banyak perhatian para banker konvensional yang kemudian membuka kantor-kantor cabang bank Islam (Rifai, 2008), sebagai sebuah lembaga keuangan yang masih relatif baru, keberadaan bank syariah merupakan keberhasilan dan kebanggaan tersendiri bagi umat Islam yang konsisten melaksanakan ajaran agama (Muhammad, 2005). Oleh karena itu industri perbankan di Indonesia semakin diramaikan dengan adanya bank syariah yang tumbuh pesat, yang menawarkan produk keuangan dan investasi dengan cara berbeda dengan bank konvensional.

Menurut UU Nomor 21 Tahun 2008 tentang perbankan syariah, bank wajib memelihara tingkat kesehatannya. Kesehatan bank harus dipelihara dan/atau ditingkatkan agar kepercayaan masyarakat terhadap bank dapat tetap terjaga. Selain itu, tingkat kesehatan bank digunakan sebagai salah satu sarana dalam melakukan evaluasi terhadap kondisi dan permasalahan yang dihadapi bank serta menentukan tindak lanjut untuk mengatasi kelemahan atau permasalahan bank, baik berupa corrective action oleh bank maupun supervisory action oleh Otoritas Jasa Keuangan. Kesehatan bank yang merupakan cerminan kondisi dan kinerja bank merupakan sarana bagi otoritas pengawas dalam menetapkan strategi dan fokus pengawasan terhadap bank. Selain itu, kesehatan bank juga menjadi kepentingan semua pihak terkait, baik pemilik, pengelola (manajemen), dan masyarakat pengguna jasa Bank (Peraturan Otoritas Jasa Keuangan Nomor 8/POJK.03/2014).

Kebijakan tersebut pada dasarnya ditujukan untuk menciptakan dan memelihara kesehatan bank. Kesehatan atau kondisi keuangan dan non keuangan bank merupakan kepentingan semua pihak terkait tersebut untuk mengevaluasi kinerja bank dalam menerapkan prinsip kehati-hatian, kepatuhan terhadap ketentuan yang berlaku dan manajemen risiko. Apabila suatu sistem perbankan dalam kondisi yang tidak sehat, maka fungsi bank sebagai lembaga intermediasi tersebut, dan alokasi serta penyediaan dana dari perbankan untuk kegiatan investasi dan membiayai sektor-sektor yang produktif dalam perekonomian menjadi terbatas. Sistem perbankan yang tidak sehat juga akan mengakibatkan lalu lintas pembayaran yang dilakukan oleh sistem perbankan tidak lancar dan 
efisien. Selain itu, sistem perbankan yang tidak sehat juga akan menghambat efektivitas kebijakan moneter (Bank Indonesia, 2003).

Untuk mengetahui dan tingkat kinerja keuangan pada bank syariah dapat diukur melalui Laporan keuangan yang dianalisis dengan menggunakan alat ukur yaitu rasio keuangan. Rasio dapat menggambarkan suatu hubungan antara jumlah tertentu dengan jumlah yang lainnya. Analisis yang dilakukan terhadap laporan keuangan tersebut kemudian dapat digunakan sebagai gambaran tentang kondisi perusahaan. Rasio keuangan digunakan untuk membandingkan angka-angka yang ada dalam laporan keuangan dengan cara membagi suatu angka dengan angka lainnya. Perbandingan dapat dilakukan antara satu komponen dengan komponen dalam satu laporan keuangan atau antar komponen yang ada diantara laporan keuangan. Kemudian angka yang diperbandingkan dapat berupa angka-angka dalam satu periode maupun beberapa periode (Kasmir, 2010); (Adisetiawan, 2012a); (Adisetiawan, 2012b)

Dalam penelitian ini terbatas pada laporan keuangan Bank Syariah selama periode 2012-2016 yang termasuk kategori sehat, cukup sehat, kurang sehat atau tidak sehat dengan menggunakan metode RGEC yaitu menilai resiko dengan rasio Non Performing Financing (NPF) dan Financing to Deposit Ratio (FDR), menilai Good Corporate Governance dengan hasil sistem self assessment, menilai earning dengan rasio Return On Asset (ROA), menilai manajemen dengan rasio Net Interest Margin (NIM), dan menilai capital dengan rasio Capital Adquency Ratio (CAR).

Tabel 1

Data Non Performing Financing (NPF), Financing to Deposit Ratio (FDR), Good Corporate Governance (GCG), Return On Asset (ROA), Net Interest Margin (NIM) dan Capital Adquency Ratio (CAR) Bank Syariah

\begin{tabular}{|c|c|c|c|c|c|c|c|}
\hline Nama & Tahun & NPF & FDR & GCG & ROA & NIM & CAR \\
\hline Bank & Penelitian & $(\%)$ & $\%$ & (Peringkat) & $\%$ & $\%$ & $\%$ \\
\hline \multirow[t]{5}{*}{ BMI } & 2012 & 1.80 & 94.15 & 1 & 1.54 & 4.64 & 11.57 \\
\hline & 2013 & 1.56 & 99.99 & 1 & 0.50 & 4.64 & 14.05 \\
\hline & 2014 & 4.85 & 84.14 & 3 & 0.17 & 3.36 & 13.90 \\
\hline & 2015 & 4.20 & 90.30 & 3 & 0.20 & 4.09 & 12.00 \\
\hline & 2016 & 1.40 & 95.13 & 2 & 0.22 & 3.21 & 12.74 \\
\hline \multirow[t]{5}{*}{ BSM } & 2012 & 1.14 & 94.40 & 2 & 2.25 & 7.25 & 13.82 \\
\hline & 2013 & 2.29 & 89.37 & 2 & 1.53 & 7.25 & 14.10 \\
\hline & 2014 & 4.29 & 82.13 & 2 & 0.04 & 6.20 & 14.12 \\
\hline & 2015 & 4.05 & 81.99 & 1 & 0.56 & 5.75 & 12.85 \\
\hline & 2016 & 3.13 & 79.19 & 1 & 0.59 & 6.16 & 14.01 \\
\hline \multirow[t]{5}{*}{ BRIS } & 2012 & 2.09 & 103.07 & 1 & 0.88 & 7.33 & 11.91 \\
\hline & 2013 & 3.26 & 102.70 & 1 & 1.15 & 6.27 & 14.49 \\
\hline & 2014 & 3.65 & 93.90 & 2 & 0.08 & 6.04 & 12.89 \\
\hline & 2015 & 3.89 & 84.16 & 2 & 0.77 & 6.38 & 13.94 \\
\hline & 2016 & 3.19 & 81.42 & 2 & 0.95 & 6.37 & 20.63 \\
\hline \multirow[t]{5}{*}{ BNIS } & 2012 & 1.42 & 84.99 & 1 & 1.48 & 11.03 & 12.79 \\
\hline & 2013 & 1.13 & 97.86 & 1 & 1.37 & 9.51 & 10.92 \\
\hline & 2014 & 1.04 & 92.60 & 2 & 1.27 & 8.15 & 17.82 \\
\hline & 2015 & 1.46 & 91.94 & 2 & 1.43 & 8.25 & 17.25 \\
\hline & 2016 & 1.64 & 84.57 & 2 & 1.44 & 8.32 & 16.85 \\
\hline
\end{tabular}

Sumber: Annual Report Bank Syariah 2012-2016 


\section{Tinjauan Pustaka}

Tingkat kesehatan perbankan penting artinya untuk meningkatkan efisiensi dalam menjalankan usahanya, sehingga kemampuan untuk memperoleh keuntungan dapat ditingkatkan dan untuk menghindari adanya potensi kebangkrutan. Tingkat kesehatan bank merupakan hasil penilaian kualitatif atas berbagai aspek yang berpengaruh terhadap kondisi atau kinerja suatu bank melalui penilaian faktor permodalan, kualitas asset, manajemen, rentabilitas, dan likuiditas. Penilaian terhadap faktor-faktor tersebut dilakukan melalui penilaian kuantitatif dan atau kualitatif setelah mempertimbangkan unsur judgement yang didasarkan atas materialitas dan signifikan dari faktor-faktor penilaian serta pengaruh dari faktor lainnya seperti kondisi industri perbankan dan perekonomian nasional. (Surat Edaran Bank Indonesia No. 6/23/DPNP tanggal 31 Mei 2004).

Tingkat kesehatan bank menurut Kasmir (2010) dapat diartikan sebagai kemampuan suatu bank untuk melakukan kegiatan operasional perbankan secara normal dan mampu memenuhi semua kewajibannya dengan baik dengan cara-cara yang sesuai dengan peraturan perbankan yang berlaku. Menurut Peraturan Bank Indonesia No. 6/10/PBI tanggal 12 April 2004 mengenai Sistem Penilaian Tingkat Kesehatan Bank Umum, kriteria penetapan peringkat komposit dapat digolongkan menjadi 5 peringkat komposit yaitu sebagai berikut :

\section{Tabel 2}

\section{Peringkat Komposit}

\begin{tabular}{cl}
\hline Peringkat & \multicolumn{1}{c}{ Keterangan } \\
\hline 1 & $\begin{array}{l}\text { Mencerminkan bahwa bank tergolong sangat baik dan mampu } \\
\text { mengatasi pengaruh negatif kondisi perekonomian dan industri }\end{array}$ \\
& keuangan \\
& Mencerminkan bahwa bank tergolong baik dan mampu mengatasi \\
& pengaruh negatif namun bank masih memiliki kelemahan-kelemahan \\
& minor yang dapat segera diatasi oleh tindakan rutin \\
& Mencerminkan bahwa bank tergolong cukup baik namun \\
& terdapat beberapa kelemahan yang dapat menyebabkan peringkat \\
& kompositnya memburuk apabila bank tidak segera melakukan tindakan \\
& korektif. \\
& Mencerminkan bahwa bank tergolong kurang baik dan sensitif terhadap \\
& negatif kondisi perekonomian dan industri keuangan atau bank \\
& memiliki kelemahan keuangan yang serius atau kombinasi dari kondisi \\
& beberapa faktor yang tidak memuaskan, yang apabila tidak dilakukan \\
tindakan koraktif yang efektif berpotensi mengalami kesulitan yang & \\
& membahayakan kelangsungan usahanya. \\
& Mencerminkan bahwa bank tergolong tidak baik dan sangat sensitif \\
& terhadap pengaruh negatif kondisi perekonomian dan industri keuangan \\
& serta mengalami kesulitan yang membahayakan kelangsungan \\
& usahanya.
\end{tabular}

Sumber: Peraturan Bank Indonesia No. 6/10/PBI tanggal 12 April 2004

Surat Edaran (SE) Bank Indonesia No.13/24/DPNP tanggal 25 Oktober 2011 tentang Penilaian Tingkat Kesehatan Bank Umum tersebut merupakan petunjuk pelaksanaan dari Peraturan Bank Indonesia No.13/1/PBI/2011, yang mewajibkan Bank Umum untuk melakukan penilaian sendiri (self assessment) 
tingkat kesehatan bank dengan menggunakan pendekatan risiko (Risk-based Bank Rating) baik secara individual maupun secara konsolidasi. Selain itu, dalamSurat Edaran (SE) tersebut terdapat prinsip- prinsip yang digunakan untuk menilai tingkat kesehatan bank, yaitu sebagai berikut berorientasi risiko, materialitas dan signifikansi, komprehensif dan terstruktur.

\section{Gambar 1}

Siklus Periode Penilaian Tingkat Kesehatan Bank

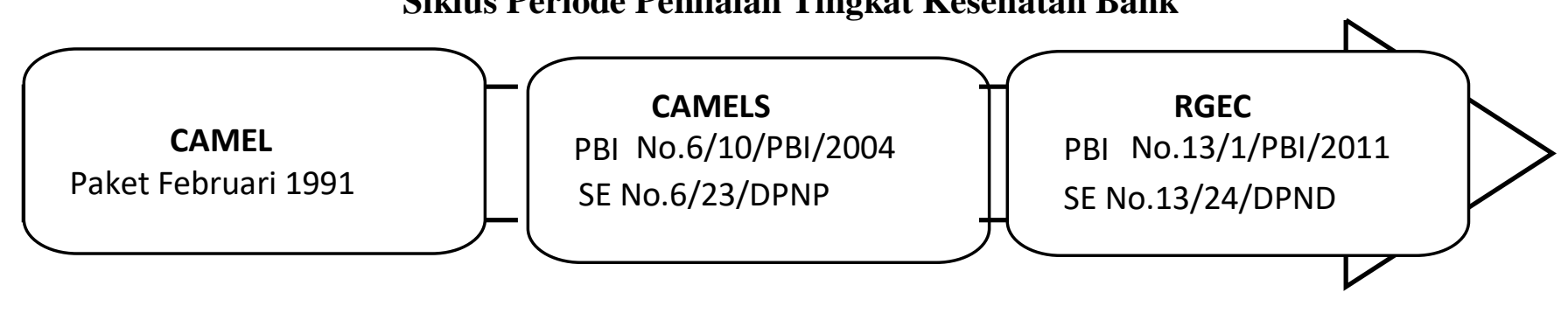

Mengingat pesatnya perkembangan sektor perbankan dan perubahan kompleksitas usaha serta profil risiko bank, dan juga adanya perubahan metodologi dalam penilaian kondisi bank yang diterapkan secara Internasional. Pengalaman dari krisis keuangan global telah mendorong perlunya peningkatan efektifitas penerapan manajemen risiko dan GCG. Tujuannya adalah agar bank mampu mengidentifikasi masalah secara lebih dini, melakukan tindak lanjut perbaikan yang sesuai dan lebih cepat, serta menerapkan GCG manajemen risiko yang lebih baik sehingga bank lebih tahan dalam menghadapi krisis (SE Bank Indonesia No. 13/24/DPNP tahun 2011). Kinerja bank atau tingkat kesehatan bank syariah dapat dinilai dengan metode RGEC.

Analisis CAMELS digunakan untuk menganalisis dan mengevaluasi kinerja keuangan bank umum di Indonesia. Analisis CAMELS diatur dalam Peraturan Bank Indonesia Nomor 6/10/PBI/2004 tentang sistem penilaian Tingkat Kesehatan Bank Umum dan Peraturan Bank Indonesia Nomor 9/1/PBI/2007 tentang Sistem Penilaian Tingkat Kesehatan Bank Umum Berdasarkan Prinsip Syariah.

Kemudian dikeluarkan PBI No. 13/1/PBI/2011 dan SE BI No.13/24/DPNP yang berlaku per Januari 2012 menggantikan penilaian kesehatan bank dengan metode CAMELS dengan metode RGEC. Metode CAMELS tersebut sudah diberlakukan selama hampir delapan tahun sejak terbitnya PBI No. 6/10/PBI/2004 dan SE No.6/23/DPNP. Dengan terbitnya PBI dan SE terbaru ini, metode CAMELS dinyatakan tidak berlaku lagi, diganti dengan model baru yang mewajibkan Bank Umum untuk melakukan penilaian sendiri (self-assessment) Tingkat Kesehatan Bank dengan menggunakan pendekatan risiko RBBR (Riskbased Bank Rating) baik secara individual maupun secara konsolidasi.

Berdasarkan peraturan Bank Indonesia No.13/1/PBI/2011 tentang Penilaian Tingkat Kesehatan Bank Umum, Bank Indonesia telah menetapkan sistem penilaian Tingkat Kesehatan Bank berbasis risiko. Menurut POJK No. 8/POJK.3/2014 faktor-faktor penilaian dalam metode RGEC yaitu sebagai berikut:

1. Risk Profile (Profil Risiko)

Peraturan Bank Indonesia No.13/1/PBI/2011 Pasal 7 ayat 1 penilaian terhadap faktor profil risiko sebagaimana dimaksud dalam pasal 6 huruf a merupakan 
penilaian terhadap risiko inheren dan kualitas penerapan manajemen risiko dalam operasional bank.

2. Good Corporate Governance (GCG)

Penilaian terhadap faktor GCG dalam pendekatan RGEC didasarkan ke dalam tiga aspek utama yaitu, governance structure, governance process, dan governance output. (Lasta, dkk., 2014).

3. Earnings (Rentabilitas)

Rentabilitas merupakan kemampuan bank dalam menghasilkan laba dari aktifitas bisnis bank. Laba merupakan hal yang sangat penting, dengan laba yang dihasilkan dari suatu kegiatan bisnis mengindikasikan bahwa kinerja yang telah dilakukan adalah baik dan dapat meneruskan kelangsungan hidup bisnis itu sendiri (Arifin, 2009).

4. Capital (Permodalan)

Meliputi penilaian terhadap tingkat kecukupan permodalan dan pengelolaan permodalan. Capital Adequacy Ratio (CAR) adalah rasio kinerja bank untuk mengukur kecukupan modal yang dimiliki bank untuk menunjang aktiva yang mengandung atau menghasilkan risiko (Kasmir, 2009).

Penilaian peringkat dari komponen masing-masing dipergunakan beberapa rasio yang dianggap mampu mewakili komponen dari metode RGEC itu sendiri. Rasio-rasio tersebut dijadikan acuan bagi peneliti untuk melakukan penilaian pada Bank Syariah yang dianggap mewakili faktor-faktor yang ada daalam aturan tersebut. Rasio-rasio tersebut dipaparkan dibawah ini, diantaranya:

Risk Profile (Profil Risiko) menggunakan rasio NPF (Non Perfoming Finance) dan rasio FDR (Finance to Deposite Ratio). Rasio NPF adalah perbandingan antara kredit bermasalah yang dimiliki oleh pihak bank denga besarnya total dana yang disalurkan menjadi kredit di masyarakat. Rasio FDR merupakan perbandingan antara jumlah dana yang disalurkan oleh oihak bank dalam bentuk kredit kepada masyarakat dengan jumlah dana pihak ketiga yang dihimpun oleh pihak bank dari masyarakat.

Good Corporate Governance merupakan tata kelola manajemen bank yang telah sesuai dengan aturan Bank Indonesia. Good Corporate Governance ini menggunakan lima prinsip dasar Good Corporate Governance yang telah ditetapkan oleh Bank Indonesia. Penentuan tingkat kesehatan dari Good Corporate Governance ditentukan menggunakan Peringkat Komposit Good Corporate Governance.

Earning (Rentabilitas) ini digunakan dua rasio dalam menilai dalam penilaian tingkat kesehatan bank. Penelitian ini menggunakan rasio ROA (Return On Asset) dan rasio NIM (Net Interest Margin). Rasio ROA merupakan perbandingan antara EBIT (Earning Before Interest and Tax) dan rata-rata total aset yang dimiliki oleh pihak bank.

Capital (Permodalan) pada penelitian ini hanya menggunakan satu rasio saja, yaitu rasio CAR (Capital Adequacy Ratio). Rasio ini merupakan perbandingan antara modal dengan ATMR (Aset Tertimbang Menurut Risiko). Modal yang dimaksudkan yaitu modal inti ditambah dengan modal pelengkap yang dimiliki oleh pihak bank. Hasil dari rasio tersebut selanjutnya akan disesuaikan dengan tabel peringkat komposit dari masing-masing faktor 


\section{Tabel 3}

Bobot Peringkat Komposit Komponen Non Performing Finance (NPF)

\begin{tabular}{cccc}
\hline No. & Peringkat Komposit & Bobot (\%) & Keterangan \\
\hline 1 & PK 1 & $<2$ & Sangat Sehat \\
2 & PK 2 & $2-3,5$ & Sehat \\
3 & PK 3 & $3,5-5$ & Cukup Sehat \\
4 & PK 4 & $5-8$ & Kurang Sehat \\
5 & PK 5 & $>8$ & Tidak Sehat \\
\hline
\end{tabular}

Sumber: Surat Edaran Bank Indonesia No. 13/24/DPNP/2011

\section{Penelitian Terdahulu}

Umiyati dan Faly (2015) meneliti tentang pengukuran kinerja bank syariah dengan menggunakan metode RGEC. Hasil uji statistik non parametrik wilcoxon testpada kinerja keuangan Bank Panin Syariah menunjukkan terdapat perbedaan yang signifikan pada rasio CAR, sedangkan pada rasio rasio NPF, FDR, ROA, ROE, dan NIM tidak menunjukkan perbedaan yang signifikan terhadap kinerja Bank Panin Syariah sebelum dan setelah go public. Mandasari (2015) mengungkapkan bahwa rasio yang digunakan pada seluruh bank BUMN menghasilkan, NPL dinyatakan baik, LDR cukup liquid, GCG pada setiap laporan bank dinyatakan sangat baik, ROA yang didapatkan Baik, NIM baik, dan ATMR yang diwakili oleh rasio CAR dikatakan sangat baik. Korompis et al. (2015) membandingkan tingkat kesehatan Bank Mandiri dan Bank Rakyat Indonesia. Hasil penelitian mengungkapkan bahwa terdapat perbedaan tingkat kesehatan antara Bank BRI dengan Bank Mandiri untuk penilaian risiko kredit yang menggunakan rasio NPL.

Hafiza dan Siti (2014) meneliti tentang kinerja bank asing dan domestik di Malaysia, yang terdiri dari bank umum, bank syariah, bank syariah Internasional, dan Bank investasi pada periode 2008 - 2012. Penilaian kinerja keuangan dalam penelitian ini menggunakan metode CAMELS. Hasil dari penelitian ini menyarankan tiga faktor yang berkontribusi untuk kinerja yang lebih baik dari lembaga perbankan di Malaysia, yaitu kecukupan permodalan dan kualitas asset.

Damayanthi dan Putri (2013) meneliti tentang penilaian kesehatan bank pada bank besar dan bank kecil pada sektor perbankan yang terdaftar pada Bursa Efek Indonesia pada tahun 2011 sampai 2012, dengan menggunakan metode RGEC. Hasil yang diperoleh dari penelitian ini adalah diantara bank besar dan bank kecil tidak terdapat perbedaan dalam hal tingkat kesehatan banknya. Penelitian tersebut mengungkapkan bahwa pentingnya penilaian tingkat kesehatan bank dilaksanakan, baik bank umum maupun bank umum syariah. Penilaian ini sebagai bagian dari peningkatan kinerja bank sebagai salah satu penggerak ekonomi nasional. Penilaian kesehatan ini akan mencerminkan kondisi dari sebuah bank (sehat atau tidak sehat) melalui faktor yang terdapat dalam metode RGEC. 


\section{Tabel 4}

Bobot Peringkat Komposit Komponen Finance to Deposit Ratio (FDR)

\begin{tabular}{cccc}
\hline No. & Peringkat Komposit & Bobot $(\%)$ & Keterangan \\
\hline 1 & PK 1 & $60-<70$ & Sangat Sehat \\
2 & PK 2 & $70-<85$ & Sehat \\
3 & PK 3 & $85-<100$ & Cukup Sehat \\
4 & PK 4 & $100-120$ & Kurang Sehat \\
5 & PK 5 & $>120:<60$ & Tidak Sehat \\
\hline
\end{tabular}

Sumber: Surat Edaran Bank Indonesia No. 13/24/DPNP/2011

Tabel 5

Bobot Peringkat Komposit Komponen Good Corporate Governance (GCG)

\begin{tabular}{cccc}
\hline No. & Peringkat Komposit & Bobot $(\%)$ & Keterangan \\
\hline 1 & PK 1 & $<1,5$ & Sangat Sehat \\
2 & PK 2 & $1,5 \leq \mathrm{NK}<2,5$ & Sehat \\
3 & PK 3 & $2,5 \leq \mathrm{NK}<3,5$ & Cukup Sehat \\
4 & PK 4 & $3,5 \leq \mathrm{NK}<4,5$ & Kurang Sehat \\
5 & PK 5 & $4,5 \leq \mathrm{NK}<5$ & Tidak Sehat \\
\hline
\end{tabular}

Sumber: Surat Edaran Bank Indonesia No. 13/24/DPNP/2011

Tabel 6

Bobot Peringkat Komposit Komponen Return On Asset (ROA)

\begin{tabular}{cccc}
\hline No. & Peringkat Komposit & Bobot (\%) & Keterangan \\
\hline 1 & PK 1 & $>2$ & Sangat Sehat \\
2 & PK 2 & $1,25-2$ & Sehat \\
3 & PK 3 & $0,5-1,25$ & Cukup Sehat \\
4 & PK 4 & $0-0,5$ & Kurang Sehat \\
5 & PK 5 & Negatif & Tidak Sehat \\
\hline
\end{tabular}

Sumber: Surat Edaran Bank Indonesia No. 13/24/DPNP/2011

Tabel 7

Bobot Peringkat Komposit Komponen Net Interest Margin (NIM)

\begin{tabular}{cccc}
\hline No. & Peringkat Komposit & Bobot $(\%)$ & Keterangan \\
\hline 1 & PK 1 & $<5$ & Sangat Sehat \\
2 & PK 2 & $2,01-5$ & Sehat \\
3 & PK 3 & $1,5-2,00$ & Cukup Sehat \\
4 & PK 4 & $0-1,49$ & Kurang Sehat \\
5 & PK 5 & Negatif & Tidak Sehat \\
\hline
\end{tabular}

Sumber: Surat Edaran Bank Indonesia No. 13/24/DPNP/2011

Tabel 8

Bobot Peringkat Komposit Komponen Capital Adequancy Ratio (CAR)

\begin{tabular}{cccc}
\hline No. & Peringkat Komposit & Bobot (\%) & Keterangan \\
\hline 1 & PK 1 & $<12$ & Sangat Sehat \\
2 & PK 2 & $9-12$ & Sehat \\
3 & PK 3 & $8-9$ & Cukup Sehat \\
4 & PK 4 & $6-8$ & Kurang Sehat \\
5 & PK 5 & $<6$ & Tidak Sehat \\
\hline
\end{tabular}

Sumber: Surat Edaran Bank Indonesia No. 13/24/DPNP/2011 
Nilai inilah yang akan dijadikan tolak ukur dalam satuan persentase untuk menentukan peringkat komposit dari seluruh komponen yang dipergunakan dalam penilaian kesehatan bank dengan metode RGEC. Selanjutnya nilai tersebut akan disesuaikan dengan tabel peringkat komposit penilaian tingkat kesehatan bank.

Tabel 9

Bobot Peringkat Komposit Penilaian Tingkat Kesehatan Bank

\begin{tabular}{cccc}
\hline No. & Peringkat Komposit & Bobot $(\%)$ & Keterangan \\
\hline 1 & PK 1 & $86-100$ & Sangat Sehat \\
2 & PK 2 & $71-85$ & Sehat \\
3 & PK 3 & $61-70$ & Cukup Sehat \\
4 & PK 4 & $41-60$ & Kurang Sehat \\
5 & PK 5 & $<40$ & Tidak Sehat \\
\hline
\end{tabular}

Sumber: Refmasari dan Setiawan (2014)

\section{METODE}

Metode data yang digunakan adalah dengan menggunakan data Sekunder. Data kuantitatif merupakan jenis data yang dipergunakan pada penelitian ini yang bersumber dari annual report yang diperoleh melalui website resmi perusahaan, sehingga pengumpulan data dalam penelitian ini yaitu menggunakan metode observasi nonpartisipan. Jenis penelitian ini adalah penelitian kuantitatif dengan menggunakan pendekatan studi kasus (case study).

Populasi pada penelitian ini terdiri dari 13 Bank Umum Syariah yang tercatat di Perbankan Indonesia (Infosyariah:2017) selama periode 2012-2016. Metode penarikan sample yang dipakai dalam penelitian ini adalah metode purposive sampling yaitu penarikan sampel dengan pertimbangan tertentu dan kriteria yang diterapkan terhadap elemen sampel. Adapun kriteria-kriteria yang dimaksud adalah:

1. Bank Umum Syariah yang sudah berdiri sejak tahun 2011 dan masih beroperasi selama periode 2012-2016.

2. Menyediakandata laporan keuangan publikasi dan rasio keuangan secara lengkap sesuai variabel yang akan diteliti selama periode tahun 2012-2016.

3. Selama periode tahun 2012-2016 secara periodik mempublikasikan laporan keuangan dan laporan GCG bank.

Oleh sebab itu, diperoleh 4 sample yang digunakan dalam penelitian, yaitu terdiri dari PT.Bank Muamalat (Persero) Tbk; PT.Bank Syariah Mandiri (Persero) Tbk; PT.Bank BRI Syariah (Persero) Tbk; dan PT.Bank BNI Syariah (Persero) Tbk. Objek penelitian ini yaitu komponen dari RGEC itu sendiri, antara lain adalah Risk Profile, Good Corporate Governance, Earning, Capital dari ke empat Bank Syariah tersebut dalam menilai tingkat kesehatan bank.

Adapun alat uji statistik yang digunakan dalam penelitian ini adalah menggunakan aplikasi SPSS v.20. Karena data yang digunakan data sekunder, maka untuk menentukan ketepatan model perlu dilakukan pengujian atas beberapa asumsi klasik yang mendasari model regresi. Model regresi linier berganda dapat disebut sebagai model yang baik jika model tersebut memenuhi asumsi normalitas data dan terbebas dari asumsi klasik statistik, baik itu multikolinieritas, autokorelasi dan heteroskedatisitas.

Regresi Linier Berganda bertujuan menguji hubungan pengaruh antara satu variabel terhadap variabel lain. Variabel yang dipengaruhi satu variabel disebut 
variabel tergantung atau dependen sedangkan variabel yang mempengaruhi disebut variabel bebas atau variabel independen.

Koefisien determinasi $\left(\mathrm{R}^{2}\right)$ bertujuan untuk mengetahui seberapa besar kemampuan variabel independen menjelaskan variabel dependen. Koefisien determinasi terletak pada Model Summary dan tertulis $R$ Square. Namun untuk regresi linier berganda sebaiknya mengunakan $R$ Square yang sudah disesuaikan atau ditulis Adjusted $R$ Square, karena disesuaikan dengan jumlah variabel independen yang digunakan dalam penelitian. Nilai R Square dikatakan baik jika di atas 0,5 karena nilai $\mathrm{R}$ Square berkisar antara 0 sampai 1 .

Uji Simultan dengan F-Test (ANOVA), hasilnya menunjukkan variabel independen secara bersama-sama berpengaruh terhadap variabel dependen jika pvalue lebih kecil dari level of significant yang ditentukan atau F hitung lebih besar dari F tabel.

a. Hipotesis Statistik:

Ho : secara keseluruhan variabel bebas tidak memiliki pengaruh yang signifikan terhadap variabel terikatnya.

$\mathrm{Ha}$ : secara keseluruhan variabel bebas memiliki pengaruh yang signifikan terhadap variabel terikatnya.

b. Kriteria Pengambilan Keputusan:

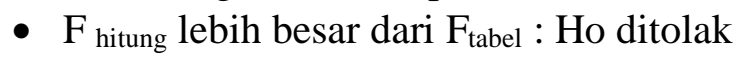

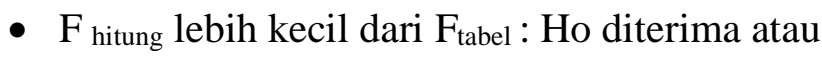

- Jika Probabilitas <0.05, maka Ho ditolak

- Jika Probabilitas >0.05, maka Ho diterima

Uji Parsial dengan T-Test bertujuan untuk mengetahui besarnya pengaruh masingmasing variabel independen secara individual (parsial) terhadap variabel dependen.

c. Hipotesis Statistik:

Ho : secara parsial variabel bebas tidak memiliki pengaruh signifikan terhadap variabel terikatnya.

$\mathrm{Ha}$ : secara parsial variabel bebas memiliki pengaruh signifikan terhadap variabel terikatnya.

d. Kriteria Pengambilan Keputusan:

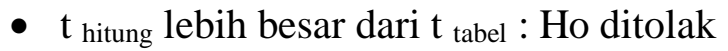

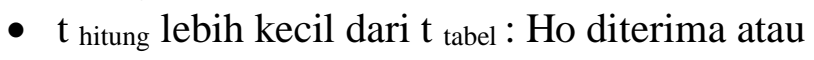

- Jika Probabilitas <0.05, maka Ho ditolak

- Jika Probabilitas > 0.05, maka Ho diterima

\section{HASIL}

Analisis Data

a. Uji Asumsi Klasik Statistik

Uji normalitas bertujuan untuk menguji apakah model regresi, variabel dependen dan independen atau keduanya memiliki distribusi normal atau mendekati normal. Berdasarkan Kolmogrov-Smirnov Test diperoleh nilai Asymp.Sig. sebesar 0,921 yang nilainya di atas 0,05. Hal ini menunjukkan bahwa uji normalitas telah terpenuhi. Uji multikolineritas bertujuan untuk menguji apakah model regresi ditemukan adanya korelasi antar variabel independen. Model regresi yang baik seharusnya tidak terjadi korelasi diantara variabel independen. Hasil dari pengujian multikolineritas diperoleh bahwa keenam variabel tersebut memiliki angka VIF $<10$ dan nilai tolerance tidak 
kurang dari 0.10 maka tidak terjadi adanya gejala multikolineritas. Uji autokorelasi bertujuan untuk mengetahui apakah terjadi korelasi antara anggota serangkaian data observasi yang diurutkan menurut waktu (time series). Hasil dari pengujian autokorelasi pada penelitian ini diperoleh nilai Durbin Watson sebesar 2.116 yang menujukan tidak adanya autokorelasi. Uji Heteroskedastisitas bertujuan untuk menguji apakah dalam model regresi terjadi ketidaksamaan variance dari residual satu pengamatan ke pengamatan yang lain. Gejala heteroskedastisitas terjadi apabila disturbance terms untuk setiap observasi tidak lagi konstan tetapi bervariasi. Berdasarkan hasil dapat diketahui bahwa semua variabel tidak terdapat heteroskedastisitas. Dengan demikian, persamaan regresi dapat diteruskan ke dalam pengujian hipotesis penelitian.

b. Uji Regresi Linier Berganda

Analisis statistik yang digunakan dalam penelitian ini adalah regresi linier berganda. Analisis ini digunakan untuk mengetahui besarnya pengaruh variabel bebas (independen) yaitu NPF, FDR, GCG, ROA, NIM dan CAR terhadap variabel terikat (dependen) yaitu Tingkat Kesehatan (Y). Besarnya pengaruh variabel independen terhadap variabel dependen secara bersama-sama dapat dihitung melalui suatu persamaan regresi linier berganda. Berdasarkan perhitungan melalui komputer dengan menggunakan SPSS diperoleh hasil sebagai berikut:

Tabel 10

Hasil Estimasi Regresi

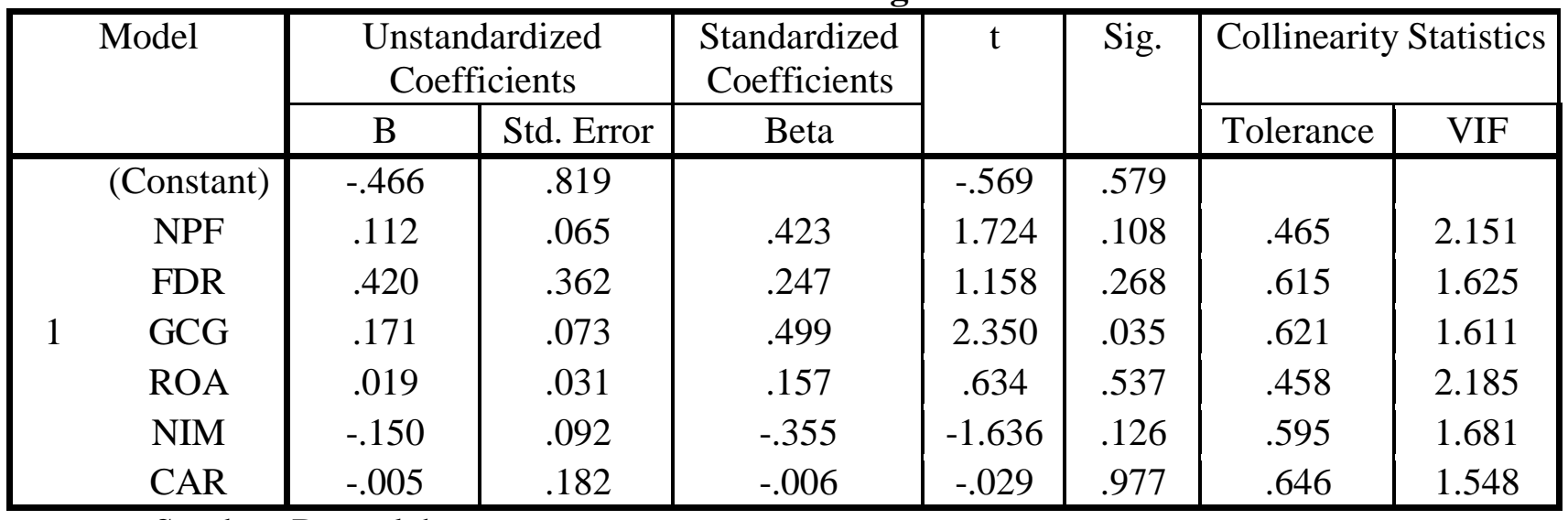

Sumber: Data olahan

Tabel 10 dapat dilihat hubungan variabel NPF, FDR, GCG, ROA, NIM dan CAR (independen) terhadap tingkat kesehatan bank (dependen). Sehingga dapat diketahui persamaan regresi yang terbentuk. Adapun persamaan regresi linier yang terbentuk adalah sebagai berikut:

$\mathrm{Y}=-0,466+0,112 \mathrm{NPF}+0,420 \mathrm{FDR}+0,171 \mathrm{GCG}+0,019 \mathrm{ROA}-0,150 \mathrm{NIM}-$ $0,005 \mathrm{CAR}$

Hasil analisis regresi linier berganda tersebut diatas dapat diketahui bahwa konstanta adalah sebesar $-0,466$ artinya apabila tidak terdapat variabel independen seperti NPF, FDR, GCG, ROA, NIM dan CAR maka besarnya tingkat kesehatan bank adalah sebesar -0,466 dengan asumsi besarnya variabelvariabel yang lain tidak berubah. 
Koefisien regresi NPF pada pengujian tersebut sebesar 0.112 artinya NPF memiliki pengaruh positif terhadap tingkat kesehatan bank dimana bila variabel NPF naik 1\% maka tingkat kesehatan bank akan mengalami peningkatan sebesar 0.112 dengan asumsi variabel lain dianggap tetap. Koefisien regresi FDR pada pengujian tersebut sebesar 0.420 artinya FDR memiliki pengaruh positif terhadap tingkat kesehatan bank dimana bila variabel FDR naik 1\% maka tingkat kesehatan bank akan mengalami peningkatan sebesar 0.420 dengan asumsi variabel lain dianggap tetap. Koefisien regresi GCG pada pengujian tersebut sebesar 0.171 artinya GCG memiliki pengaruh positif terhadap tingkat kesehatan bank dimana bila variabel GCG naik 1\% maka tingkat kesehatan bank akan mengalami peningkatan sebesar 0.171 dengan asumsi variabel lain dianggap tetap. Koefisien regresi ROA pada pengujian tersebut sebesar 0.019 artinya ROA memiliki pengaruh positif terhadap tingkat kesehatan bank dimana bila variabel ROA naik $1 \%$ maka tingkat kesehatan bank akan mengalami peningkatan sebesar 0.019 dengan asumsi variabel lain dianggap tetap. Koefisien regresi NIM pada pengujian tersebut sebesar -0.150 artinya NIM memiliki pengaruh negative terhadap tingkat kesehatan bank dimana bila variabel NIM naik 1\% maka tingkat kesehatan akan mengalami penurunan sebesar -0.150 dengan asumsi variabel lain dianggap tetap. Koefisien regresi CAR pada pengujian tersebut sebesar -0.005 artinya CAR memiliki pengaruh negative terhadap tingkat kesehatan bank dimana bila variabel CAR naik $1 \%$ maka tingkat kesehatan akan mengalami penurunan sebesar -0.005 dengan asumsi variabel lain dianggap tetap. Setelah dilakukan perhitungan regresi dengan menggunakan rumus persamaan diatas, maka langkah pengujian statistik untuk menguji hipotesis dalam penulisan ini dilanjutkan dengan uji koefisien determinasi $\left(\mathrm{R}^{2}\right)$, uji anova (uji F) dan uji parsial (uji t)

c. Koefisien Determinasi

Koefisien determinasi digunakan untuk mengukur seberapa jauh kemampuan model dalam menerangkan variasi variabel independen. Hasil pengujian koefisiensi determinasi dapat dilihat pada tabel berikut ini:

Tabel 11

Hasil Koefisiensi Determinasi

\begin{tabular}{|l|c|r|r|r|r|}
\hline Model & $\mathrm{R}$ & $\mathrm{R}$ Square & Adjusted R Square & $\begin{array}{c}\text { Std. Error of the } \\
\text { Estimate }\end{array}$ & Durbin-Watson \\
\hline 1 & $.798^{\mathrm{a}}$ & .636 & .468 & .0434657 & 2.116 \\
\hline
\end{tabular}

Sumber: Data olahan

Berdasarkan data tersebut diatas dapat diperoleh nilai Adjusted R Square $\left(\mathrm{R}^{2}\right)$ sebesar 0.636 . Hal ini berarti bahwa $64 \%$ variasi tingkat kesehatan dapat dijelaskan oleh variasi dari variabel independen (NPF, FDR, GCG, ROA, NIM dan CAR). Sedangkan sisanya yaitu $36 \%$ dijelaskan oleh sebab-sebab diluar model.

d. Uji F-test (Anova)

Uji F-test (ANOVA) dimaksudkan untuk mengetahui pengaruh variabelvariabel independen (NPF, FDR, GCG, ROA, NIM dan CAR) secara simultan (bersama-sama) terhadap tingkat kesehatan bank pada tahun 20122016. 
Tabel 12

Uji F-test

\begin{tabular}{|ll|r|r|r|r|r|}
\hline Model & & Sum of Squares & df & Mean Square & \multicolumn{1}{c|}{ F } & \multicolumn{1}{c|}{ Sig. } \\
\hline \multirow{3}{*}{1} & Regression & .043 & 6 & .007 & 3.786 & $.021^{\mathrm{b}}$ \\
& Residual & .025 & 13 & .002 & & \\
& Total & .067 & 19 & & & \\
\hline
\end{tabular}

Sumber: data olahan

Hasil perhitungan diperoleh nilai $\mathrm{F}$ hitung sebesar 3,786 dengan tingkat signifikan sebesar 0.021. Hal ini berarti nilai signifikan lebih kecil dari tingkat kepercayaan 5\% yang menunjukkan hasil uji ini menolak $\mathrm{H}_{0}$ dan menerima $\mathrm{H}_{1}$. Dari hasil uji anova ini dapat disimpulkan bahwa variabel NPF, FDR, GCG, ROA, NIM dan CAR secara bersama-sama mempunyai pengaruh terhadap tingkat kesehatan bank dan dapat disimpulkan bahwa model dalam penelitian ini layak untuk diteliti (goodness of fit).

e. Uji t-test (Parsial)

Secara parsial pengaruh dari enam variabel independen tersebut terhadap tingkat kesehatan bank ditunjukkan pada Tabel 12 sebagai berikut:

Tabel 13.

Uji t-test

\begin{tabular}{|c|c|c|c|c|c|c|c|c|}
\hline \multirow{2}{*}{\multicolumn{2}{|c|}{ Model }} & \multicolumn{2}{|c|}{$\begin{array}{c}\text { Unstandardized } \\
\text { Coefficients }\end{array}$} & \multirow{2}{*}{$\begin{array}{c}\begin{array}{c}\text { Standardized } \\
\text { Coefficients }\end{array} \\
\text { Beta }\end{array}$} & \multirow[t]{2}{*}{$\mathrm{t}$} & \multirow[t]{2}{*}{ Sig. } & \multicolumn{2}{|c|}{$\begin{array}{l}\text { Collinearity } \\
\text { Statistics }\end{array}$} \\
\hline & & B & Std. Error & & & & Tolerance & VIF \\
\hline \multirow{7}{*}{1} & $\begin{array}{c}\text { Constant } \\
\text { ) }\end{array}$ & -.466 & .819 & & -.569 & .579 & & \\
\hline & NPF & .112 & .065 & .423 & 1.724 & .108 & .465 & 2.151 \\
\hline & FDR & .420 & .362 & .247 & 1.158 & .268 & .615 & 1.625 \\
\hline & GCG & .171 & .073 & .499 & 2.350 & .035 & .621 & 1.611 \\
\hline & ROA & .019 & .031 & .157 & .634 & .537 & .458 & 2.185 \\
\hline & NIM & -.150 & .092 & -.355 & -1.636 & .126 & .595 & 1.681 \\
\hline & CAR & -.005 & .182 & -.006 & -.029 & .977 & .646 & 1.548 \\
\hline
\end{tabular}

Sumber: data olahan

Analisis ini dilakukan untuk mengetahui pengaruh variabel bebas terhadap variabel terikat. Pengujian hipotesis dilakukan dengan cara membandingkan antara nilai probabilitas (sig). apabila terlihat angka signifikansi lebih kecil dari 0.05 maka $\mathrm{H}_{0}$ ditolak dan $\mathrm{H}_{1}$ diterima, yang berarti bahwa variabel bebas berpengaruh secara signifikan terhadap variabel terikat. Begitu pula sebaliknya, jika angka signifikansi lebih besar dari 0.05 maka $\mathrm{H}_{0}$ diterima dan $\mathrm{H}_{1}$ ditolak, yang berarti bahwa variabel bebas tidak berpengaruh secara signifikan terhadap variabel terikat.

Uji signifikansi masing-masing variabel diuraikan sebagai berikut :

a. Pengaruh Variabel NPF terhadap Tingkat Kesehatan Bank

Hasil penelitian diperoleh variabel NPF memiliki nilai signifikan sebesar 0,108 lebih besar dari 0,05, artinya secara parsial rasio NPF tidak berpengaruh signifikan terhadap tingkat kesehatan bank. 
b. Pengaruh Variabel FDR terhadap Tingkat Kesehatan Bank

Hasil penelitian diperoleh variabel FDR memiliki nilai signifikan sebesar 0,268 lebih besar dari 0,05, artinya secara parsial rasio FDR tidak berpengaruh signifikan terhadap tingkat kesehatan bank.

c. Pengaruh Variabel GCG terhadap Tingkat Kesehatan Bank

Hasil penelitian diperoleh variabel GCG memiliki nilai signifikan sebesar 0,035 lebih kecil dari 0,05, artinya secara parsial rasio GCG berpengaruh signifikan terhadap tingkat kesehatan bank.

d. Pengaruh Variabel ROA terhadap Tingkat Kesehatan Bank

Hasil penelitian diperoleh variabel ROA memiliki nilai signifikan sebesar 0.537 lebih besar dari 0,05 , artinya secara parsial rasio ROA tidak berpengaruh signifikan terhadap tingkat kesehatan bank.

e. Pengaruh Variabel NIM terhadap Tingkat Kesehatan Bank

Hasil penelitian diperoleh variabel NIM memiliki nilai signifikan sebesar 0.126 lebih besar dari 0,05 , artinya secara parsial rasio NIM tidak berpengaruh signifikan terhadap tingkat kesehatan bank.

f. Pengaruh Variabel CAR terhadap Tingkat Kesehatan Bank

Hasil penelitian diperoleh variabel CAR memiliki nilai signifikan sebesar 0.977 lebih besar dari 0,05, artinya secara parsial rasio CAR tidak berpengaruh signifikan terhadap tingkat kesehatan bank.

Setelah dilakukan perhitungan rasio kinerja keuangan maka selanjutnya akan dilakukan penilaian kesehatan bank dengan menggunakan metode RGEC. Hal ini dimaksudkan untuk dapat menilai apakah kinerja keuangan dapat dikategorikan sehat.

Tabel 14

\begin{tabular}{|c|c|c|c|c|c|c|c|c|c|c|c|c|c|c|}
\hline \multirow{2}{*}{$\begin{array}{l}\text { Nama } \\
\text { Bank }\end{array}$} & \multirow{2}{*}{\begin{tabular}{|c|} 
Tahun \\
Penelitian
\end{tabular}} & \multicolumn{2}{|c|}{ NPF } & \multicolumn{2}{|c|}{ FDR } & \multirow{2}{*}{\begin{tabular}{|c|} 
GCG \\
Peringkat \\
\end{tabular}} & \multicolumn{2}{|c|}{ ROA } & \multicolumn{2}{|c|}{ NIM } & \multicolumn{2}{|c|}{ CAR } & \multirow{2}{*}{\begin{tabular}{|c|} 
KSB \\
Peringkat \\
\end{tabular}} & \multirow{2}{*}{ Ket. } \\
\hline & & $\%$ & Peringkat & $\%$ & Peringkat & & $\%$ & Peringkat & $\%$ & Peringkat & $\%$ & Peringkat & & \\
\hline \multirow[t]{5}{*}{ BMI } & 2012 & 1.80 & 1 & 94.15 & 3 & 1 & 1.54 & 2 & 4.64 & 2 & 11.57 & 2 & 2 & sehat \\
\hline & 2013 & 1.56 & 1 & 99.99 & 3 & 1 & 0.50 & 4 & 4.64 & 2 & 14.05 & 1 & 2 & sehat \\
\hline & 2014 & 4.85 & 3 & 84.14 & 2 & 3 & 0.17 & 4 & 3.36 & 2 & 13.90 & 1 & 3 & cukup sehat \\
\hline & 2015 & 4.20 & 3 & 90.30 & 3 & 3 & 0.20 & 4 & 4.09 & 2 & 12.00 & 2 & 3 & cukup sehat \\
\hline & 2016 & 1.40 & 1 & 95.13 & 3 & 2 & 0.22 & 4 & 3.21 & 2 & 12.74 & 1 & 2 & sehat \\
\hline \multirow[t]{5}{*}{ BSM } & 2012 & 1.14 & 1 & 94.40 & 3 & 2 & 2.25 & 1 & 7.25 & 1 & 13.82 & 1 & 2 & sehat \\
\hline & 2013 & 2.29 & 2 & 89.37 & 3 & 2 & 1.53 & 2 & 7.25 & 1 & 14.10 & 1 & 2 & sehat \\
\hline & 2014 & 4.29 & 3 & 82.13 & 2 & 2 & 0.04 & 4 & 6.20 & 1 & 14.12 & 1 & 2 & sehat \\
\hline & 2015 & 4.05 & 3 & 81.99 & 2 & 1 & 0.56 & 3 & 5.75 & 1 & 12.85 & 1 & 2 & sehat \\
\hline & 2016 & 3.13 & 2 & 79.19 & 2 & 1 & 0.59 & 3 & 6.16 & 1 & 14.01 & 1 & 2 & sehat \\
\hline \multirow[t]{5}{*}{ BRIS } & 2012 & 2.09 & 2 & 103.07 & 4 & 1 & 0.88 & 3 & 7.33 & 1 & 11.91 & 2 & 2 & sehat \\
\hline & 2013 & 3.26 & 2 & 102.70 & 4 & 1 & 1.15 & 3 & 6.27 & 1 & 14.49 & 1 & 2 & sehat \\
\hline & 2014 & 3.65 & 3 & 93.90 & 3 & 2 & 0.08 & 4 & 6.04 & 1 & 12.89 & 1 & 2 & sehat \\
\hline & 2015 & 3.89 & 3 & 84.16 & 2 & 2 & 0.77 & 3 & 6.38 & 1 & 13.94 & 1 & 2 & sehat \\
\hline & 2016 & 3.19 & 2 & 81.42 & 2 & 2 & 0.95 & 3 & 6.37 & 1 & 20.63 & 1 & 2 & sehat \\
\hline \multirow[t]{5}{*}{ BNIS } & 2012 & 1.42 & 1 & 84.99 & 2 & 1 & 1.48 & 2 & 11.03 & 1 & 12.79 & 1 & 1 & sangat sehat \\
\hline & 2013 & 1.13 & 1 & 97.86 & 3 & 1 & 1.37 & 2 & 9.51 & 1 & 10.92 & 2 & 2 & sehat \\
\hline & 2014 & 1.04 & 1 & 92.60 & 3 & 2 & 1.27 & 2 & 8.15 & 1 & 17.82 & 1 & 2 & sehat \\
\hline & 2015 & 1.46 & 1 & 91.94 & 3 & 2 & 1.43 & 2 & 8.25 & 1 & 17.25 & 1 & 2 & sehat \\
\hline & 2016 & 1.64 & 1 & 84.57 & 2 & 2 & 1.44 & 2 & 8.32 & 1 & 16.85 & 1 & 2 & sehat \\
\hline
\end{tabular}

Penilaian Tingkat Kesehatan Bank (KSB) Periode 2012-2016

Sumber: Data olahan

Berdasarkan Tabel 14 diketahui bahwa pada penetapan kesimpulan predikat tingkat kesehatan bank yaitu terdapat sekitar 92\% bank syariah selama periode 2012-2016 menunjukkan kondisi bank yang stabil dengan predikat 
"Sehat". Ada beberapa bank yang mengalami peningkatan dan penurunan di tahun 2012 sampai tahun 2016. Bahkan ada bank yang tetap berada pada predikat

"Tidak Sehat" selama 2 (dua) periode.

Perolehan Peringkat Komposit 2 ini mencerminkan, bahwa Bank Syariah pada periode tahun 2012-2016 secara umum mampu menghadapi pengaruh negatif dari perubahan kondisi bisnis yang mungkin terjadi, baik dari faktor internal maupun eksternal lainnya. Terdapat kelemahan di dalam faktor-faktor tersebut, maka secara umum kelemahan tersebut tidak berpengaruh secara signifikan. Keberhasilan yang diperoleh oleh pihak Bank Syariah mencerminkan kinerja keuangan yang telah dicapai oleh pihak manajemen masing-masing Bank Syariah. Pencapaian ini merupakan prestasi yang perlu dipertahankan bahkan ditingkatkan untuk meningkatkan tingkat kepercayaan masyarakat.

\section{SIMPULAN}

Berdasarkan hasil perhitungan dan analisis yang telah dilakukan dalam penelitian ini maka penulis dapat mengambil kesimpulan, yaitu:

1. Variabel Besarnya pengaruh NPF, FDR, GCG, ROA, NIM dan CAR terhadap tingkat kesehatan bank yaitu sebesar $0,021<0,05$ dan Fhitung 3,785>2,85, sehingga dapat disimpulkan bahwa terdapat pengaruh signifikan secara simultan. Variabel independen mampu menjelaskan variabel dependen sebesar $64 \%$.

2. Variabel yang berpengaruh signifikan secara parsial terhadap tingkat kesehatan bank adalah variabel GCG. Sedangkan variabel NPF, FDR, ROA, NIM dan CAR memberikan pengaruh tidak signifikan terhadap tingkat kesehatan bank.

3. Predikat kinerja bank selama periode 2012-2016 dengan menggunakan metode RGEC diketahui terdapat $92 \%$ bank menunjukkan bahwa kondisi bank tersebut stabil. Artinya bank-bank umum dapat dikategorikan bank yang "Sehat".

\section{DAFTAR PUSTAKA}

Adisetiawan, R., 2012, Faktor-Faktor Keuangan yang Dapat Memprediksi Kebangkrutan Suatu Bank dengan Metode Logistic Regression, Eksis: Jurnal Ekonomi dan Bisnis, 3(1): 57-72, Fakultas Ekonomi, Universitas Batanghari

Adisetiawan, R., 2012, Indikator Keuangan yang Dapat Memprediksi Kebangkrutan suatu Bank dengan Metode Analisis Diskriminan, Jurnal Ilmiah Universitas Batanghari, 12(2): 44-51, Universitas Batanghari

Arifin, Lasta dkk. 2014. Analisis Tingkat Kesehatan Bank Dengan Menggunakan Pendekatan Rgec (Risk Profile, Good Corporate Governance, Earnings, Capital) (Studi Pada PT Bank Rakyat Indonesia,Tbk Periode 2011-2013). Jurnal Administrasi Bisnis (JAB), Vol. 13 No. 2

Bank Indonesia. 2011. Peraturan Bank Indonesia No. 13/ 1 /PBI/2011 Tentang Penilaian Tingkat Kesehatan Bank Umum. Jakarta: Bank Indonesia

Bank Indonesia. 2011. Surat Edaran No.13/ 24 /DPNP Tentang Penilaian Tingkat Kesehatan Bank Umum. Jakarta: Bank Indonesia.

Bank Indonesia. 2013. Surat Edaran No. 15/15/DPNPTentang Pelaksanaan Good Corporate Governance bagi Bank Umum. Jakarta: Bank Indonesia.

Mandasari, Jayanti, 2015, Analisis Kinerja Keuangan Dengan Pendekatan Metode RGEC Pada Bank BUMN Periode 2012-2013, Jurnal Administrasi Bisnis

Kasmir. 2010. Analisis Laporan Keuangan. Jakarta: PT Rajawali Pers 
Kasmir. 2009. Bank dan Lembaga Keuangan Lainnya. Jakarta: Rajawali Pers.

Lasta, Heidy Arrvida dkk., 2014. Analisis Tingkat Kesehatan bank dengan menggunakan pendekatan RGEC, Jurnal Administrasi Bisnis, Universitas Brawijaya

Muhammad. 2005. Manajemen Dana Bank Syariah, Yogyakarta: Ekonisia

Peraturan Otoritas Jasa Keuangan Nomor 8/POJK.03/2014

Rifai, Veithzal dan Andria Permata Veithzal. 2008. Islamic Financial Management, Jakarta: PT Raja Grafindo Persada

Umiyati, Queenindya Permata Faly, 2015, Pengukuran Kinerja Bank Syariah dengan Metode RGEC, Jurnal Akuntansi dan Keuangan Islam, Vol.3, No.2 2015 